\title{
Historical Perspectives
}

\section{Professor Mansour Ali Haseeb: Highlights from a pioneer of biomedical research, physician and scientist}

\author{
Mustafa Abdalla M Salih, \\ International Editor, \\ Sudanese Journal of Paediatrics
}

\section{ABSTRACT}

The article highlights the career of Professor Mansour Ali Haseeb (1910 - 1973; DKSM, Dip Bact, FRCPath, FRCP [Lond]), a pioneer worker in health, medical services, biomedical research and medical education in the Sudan. After his graduation from the Kitchener School of Medicine (renamed, Faculty of Medicine, University of Khartoum [U of K]) in 1934, he devoted his life for the development of laboratory medicine. He became the first Sudanese Director of Stack Medical Research Laboratories (1952 - 1962). He made valuable contributions by his services in the vaccine production and implementation programs, most notably in combating small pox, rabies and epidemic meningitis. In 1963 he became the first Sudanese Professor of Microbiology and Parasitology and served as the first Sudanese Dean of the Faculty of Medicine, U of K (1963-1969). He was an active loyal citizen in public life and served in various fields outside the medical profession. As Mayor of
Omdurman, he was invited to visit Berlin in 1963 by Willy Brandt, Mayor of West Berlin (1957-1966) and Chancellor of the Federal Republic of Germany (1969 to 1974). Also as Mayor of Omdurman, he represented the City in welcoming Queen Elizabeth II during her visit to Sudan in February 1965. He also received State Medals from Egypt and Ethiopia. In 1973 he was appointed Chairman of the Sudan Medical Research Council, and was awarded the international Dr. Shousha Foundation Prize and Medal by the WHO for his contribution in the advancement of health, research and medical services.

Key words:

Professor Mansour Ali Haseeb; Faculty of Medicine; University of Khartoum; Sudan; Biomedical research; Medical education; Microbiology; Vaccination; Small pox; Rabies; Meningococcal meningitis; Epidemic.

\section{How to cite this:}

Salih MAM. Professor Mansour Ali Haseeb: Highlights from a pioneer of biomedical research, physician and scientist. Sudan J Paediatr 2013; 13(2):66-75. 


\section{INTRODUCTION}

Introducing the book "A Monograph on Biochemical Research in the Sudan" written by the Late Professor Mansour Ali Haseeb [1], Harry Hoogstraal stated in May 1973 that "Professor Mansour Haseeb has been more intimately associated than any other living person with adding to Sudanese biomedical knowledge and sharing vast experience with younger generations of physicians and scientists. Just this month, these contributions and accomplishments were internationally applauded when the World Health Organization presented to Professor Haseeb the prestigious Dr A.T. Shousha Prize for significant contributions to public health problems in the Eastern Mediterranean Region". Harry Hoogstraal is an American entomologist and parasitologist, who had been described as "the greatest authority on ticks and tickborn diseases who ever lived" [2]. While the manuscript was under print, Professor Haseeb passed away on Saturday $29^{\text {th }}$ September 1973. His sudden death was a great shock to all those who knew him and to the nation which he so faithfully served. The book was forwarded by Professor Elnazeer Dafaalla (1922-1982), President of the National Council for Research [3-5]. He described Professor Haseeb's research work to be " a great contribution to science which had practical application in his own country" and also added "...We who have been near to him, who have particularly appreciated his services, both scientific and public and enjoyed his friendship with all its human attributes, shall always miss him." The late Professor Elnazeer Dafaalla (1922-1982), Professor of Microbiology, was also an outstanding scholar. He was the first Dean of the Faculty of Veterinary Science, University of Khartoum (U of K) [1958-1962], Vice- Chancellor, U of K (1962-1968), Minister of Health and Social Welfare (1974-1976), and Minister of Higher Education and Guidance and the President of the National Council for Higher Education (November 1981 - December 1982).
This short account is an attempt to highlight the medical, scientific and public attributes of the Late Professor MansourAli Haseeb, as well as his pioneering contribution to biomedical research worldwide.

\section{Early life, education and biomedical contributions}

Professor Mansour Ali Haseeb was born in 1910 while his father was serving as the Judge of Algitaina in the White Nile State of Sudan. His grandfather, known as "scholar Haseeb", lived in North Sudan near Berber town, the historical starting-point of the old caravan route across the Nubian Desert to the Red Sea at Suakin $[6,7]$. He is a descendant of Majadhib clan who were known to be teachers and provided medicinal help, and mediated judicially and socially between different communities in various regions of Sudan [8,9]. Haseeb had his primary schooling divided between Berber, Atbara and Port Sudan, later graduating from Kitchener School of Medicine in 1934 winning the first Prize in medicine (Figure 1); and shortly thereafter entered the medical service of his country. In 1946 he left to the United Kingdom (UK) for postgraduate training in microbiology. Returning from the UK, he devoted his life for the development of laboratory medicine and hygiene, and was the first Sudanese director of Stack Medical Research Laboratories $(1952$ - 1962). He trained generations of doctors, technicians, laboratory assistants and other members of the medical profession. He also opened the door for Sudanese doctors to conduct original research work and contribute internationally in the field of applied medical science. His talents in research became evident early in his career when he managed to publish a case history in the British Medical Journal in June 1940 [10]. As he stated in his book [1], " Research work done in the Stack Medical Research Laboratories was of a practical 
nature and was usually initiated to solve a definite problem connected with endemic diseases. Ad hoc research was carried out as and when required to reveal the cause of an epidemic or to help in control measures." An example for this was the research done during an outbreak of virulent smallpox in the Gezira cotton-growing area in Sudan in 1938 which involved collecting variolous material from different patients, and inoculating monkeys [11]. Following a series of experiments on small pox vaccine preparation, he and Dr E S Horgan developed a successful technique for the mass production of sufficient vaccine for Sudan [12].

In 1950, he reported on successful treatment of culture-proven brucellosis by using chloramphenicol in a 30-year-old Sudanese woman, who previously showed resistance to sulphonamide treatment [13]. Since the patient was suckling a child, her milk was investigated and found to be negative for Brucella, and the child was not apparently infected.

A notable research for which he contributed crucially was made during February and March 1954[14]. This covered the western and southern edge of the Nuba Mountains of Sudan, and the plain country to the west and as far south as the Gogrial area, totaling some 2,000 miles overland. The aim was to search for evidence of yellow fever, and to evaluate the possible spread of yellow fever northward. The study involved Baggara tribesmen, Nuba villages, and Dinka people, and blood was collected from humans (mainly children) and the primate population (baboons,monkeys, and galagos). Haseeb was vital in introducing the research team and securing the confidence of each local population. This study was conducted under the auspices of the Ministry of Health of the Sudan, the Department of Virology of the United States Naval Medical Research Unit No. 3 (NAMRU-3), Cairo, Egypt, and the Division of Medicine and Public Health, of the Rockefeller Foundation, New York, N.Y., USA. The expedition was documented in a film [15]. Other research topics included small pox, relapsing fever, leishmaniasis, schistosomiasis, onchocerciasis, heat exhaustion and poliomyelitis [1].

Professor Haseeb was a prolific biomedical researcher at a time when research had to be done single-minded [1]. He contributed 40 publications as first author and many others as co-author. His publications were spread over high profile medical periodicals including Nature [16], The Lancet [17], British Medical Journal [18] and Journal of Hygiene (current name Epidemiology and Infection, published since 1901) [12]. He also published in local biomedical periodicals including Sudan Medical Journal [19] which was started in 1953 as the official organ of the Sudan Medical Association to encourage research and disseminate medical scientific knowledge among doctors [1]. Professor Haseeb was one of the pioneer editors of the Sudan Medical Journal. He also contributed articles to another local journal: Al Hakeem [20]. Al Hakeem, which translates from Arabic as wise one or doctor, is the official journal of the medical students at the Faculty of Medicine, U of K. Established in the late 1950s, it continued to publish original articles mainly written by medical students, with some contribution from the teaching staff and health professionals. $\mathrm{Al}$ Hakeem stands out as one of the earliest of its kind worldwide. 


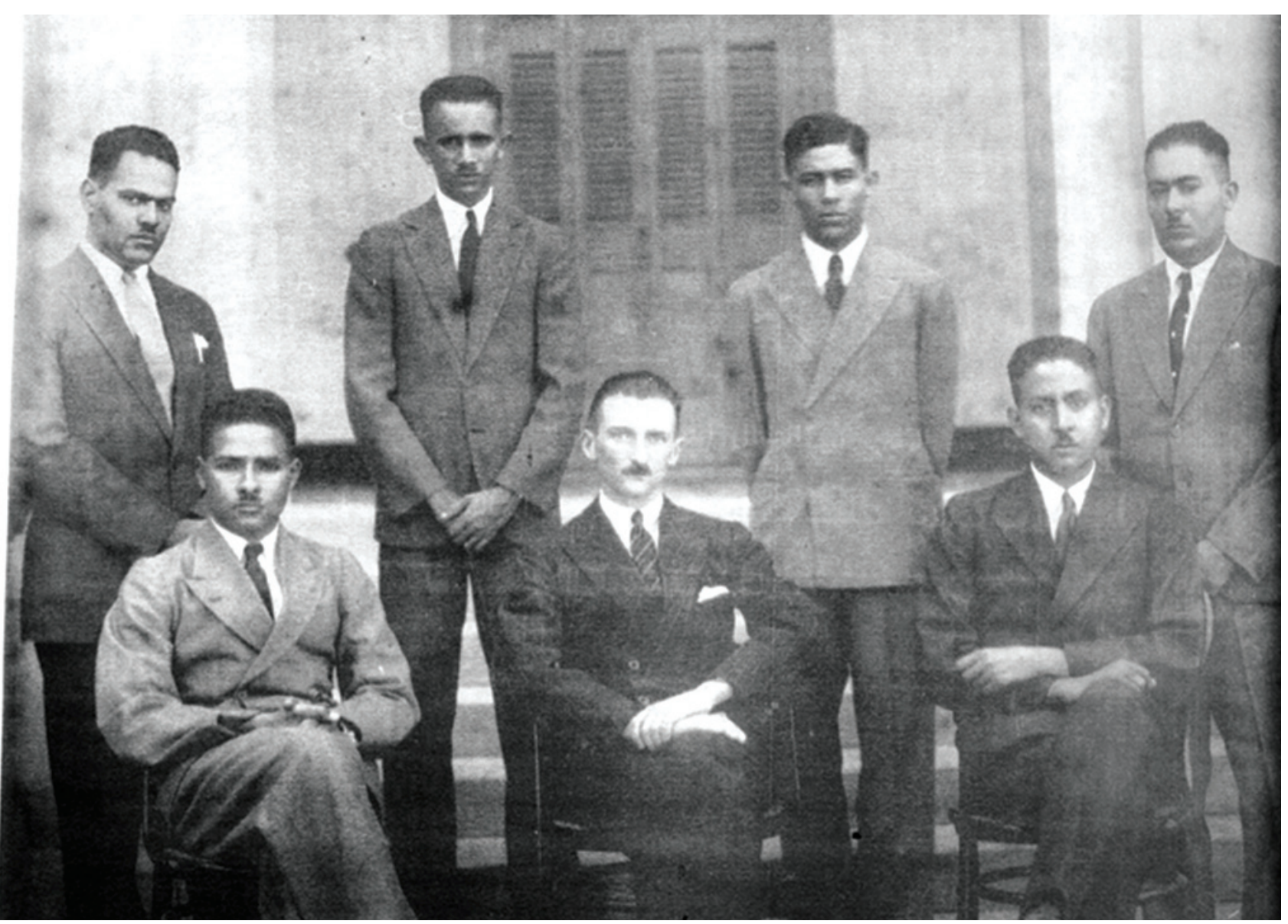

Figure 1 - Graduates of Kitchener School of Medicine in 1934. Dr Mansour Ali Haseeb sitting first from left.

\section{On Medical Education}

From 1938 to 1962 Dr Haseeb served as part-time lecturer at the Faculty of Medicine, University of Khartoum ( $\mathrm{U}$ of $\mathrm{K}$ ), teaching microbiology, physiology, pathology, forensic medicine and community medicine! In 1963 he became the first Sudanese to hold the chair of Microbiology and Parasitology and also the first Sudanese Dean of the Faculty of Medicine, U of K (Figures 2 and 3). On the basis of his publications, he was made Fellow of the Royal College of Pathologists in 1965. Four years later he was made Fellow of the Royal College of Physicians.

As Dean of the Faculty of Medicine (1963-1969), he nurtured strong connections with various educational and research centers in Europe and Africa. These included the Royal Colleges of England, the Orthopaedic Centre at Oxford and the London School of Hygiene and Tropical Medicine. A staff member of the Faculty of Medicine, U of K acted in 1965 as Secretary of the Association of Medical Schools in Africa. In 1968 the WHO Eastern Mediterranean Regional Office (EMRO) held a meeting on Medical Education in Khartoum, in which the association for Medical Schools in the Middle East was established. Professor Mansour was elected to the membership of the executive committee [1]. 


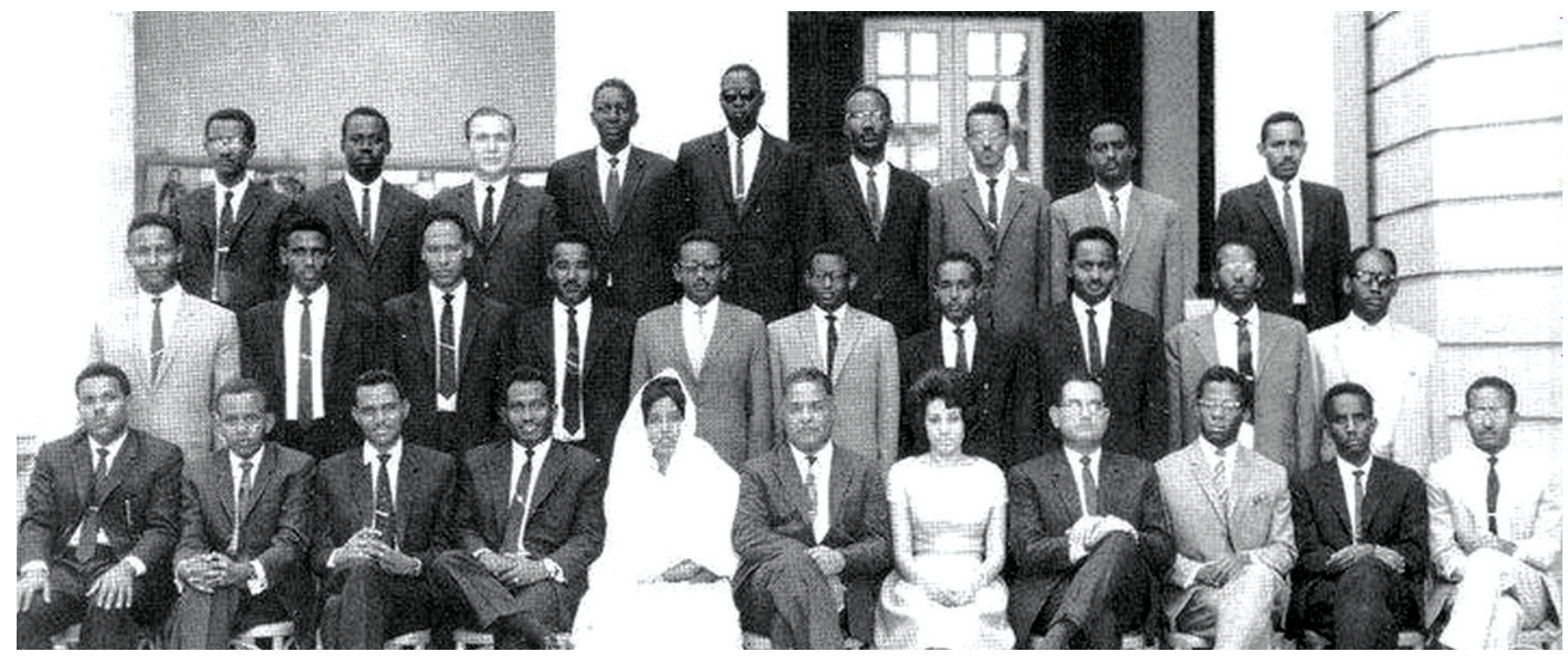

Figure 2 - Professor Mansour Ali Haseeb, Dean Faculty of Medicine, University of Khartoum (U of K) [1963- 1969] (sitting in the middle) with the Graduates in 1965. Sitting second from right: Prof Abdel-Galil M. Abdel-Gadir, Professor of Physiology,

College of Medicine, King Saud University, Riyadh, Saudi Arabia. Standing fourth from right (first row): Prof Mohamed Ibrahim Ali Omer, Ex - President of the Sudan Association of Paediatricians, and former Editor-in -Chief, Sudanese Journal of Paediatrics. Standing fourth from right (second row): The Late Prof Eldaw Mukhtar, Ex-Dean, Faculty of Medicine, U of K (1996 - 2003).

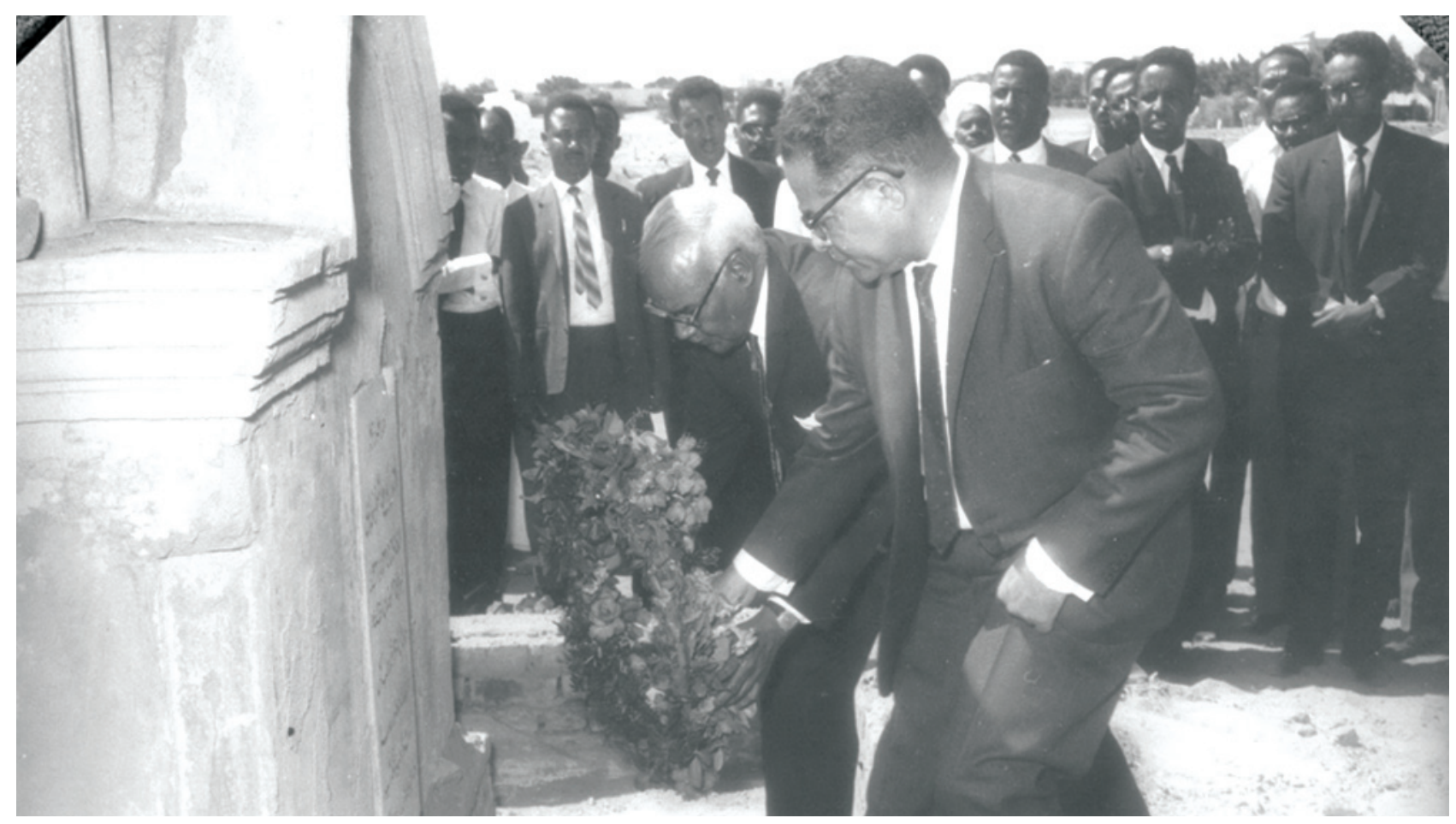

Figure 3 - Professor Mansour Ali Haseeb, Dean, Faculty of Medicine, University of Khartoum(right), laying flowers at the grave of the late philanthropist Hashim Bey Al Baghdadi [21] during the Graduate's Day in 1966. Al Bagdadi donated all of his fixed assets for the benefit of Kitchener School of Medicine. Professor Mansour was accompanied by Dr Ali Badri, one of first batch of students graduating from the Kitchener School of Medicine in 1928, and the first Minster of Health in Sudan. Standing second from right(first row): Prof Mohamed Ahmed Hassan Abdel Galil, Ex-Dean (1987- 1990) and Emeritus Professor, Faculty of Medicine, University of Khartoum. Standing third from left (first row): Prof Nasr eldin Ahmed Mahmoud, First Dean, Faculty of Medicine, University of Gezira (1975 - 1979). 


\section{Contributions to public life}

Professor Haseeb was an active loyal citizen in public life and served his country in various fields outside the medical profession. His great services in social fields, his contributions in local government and many other aspects of public life had a deep and an unforgettable effect. In all these activities he took positions of leadership and responsibility. $\mathrm{He}$ contributed significantly to the Sudanese Graduates' Club both in its Executive Committee and in its pioneering efforts to establish national schools [22].
As Mayor of Omdurman, he was invited to visit Berlin in 1963 by Willy Brandt, Mayor of West Berlin (1957-1966) who later became Chancellor of the Federal Republic of Germany (1969 to 1974) and was awarded the Nobel Peace Prize in 1971 (Figure 4). Also as Mayor of Omdurman, he represented the City in welcoming Queen Elizabeth II during her visit to Sudan in February 1965 (Figure 5). He also received State Medals from Egypt and Ethiopia.

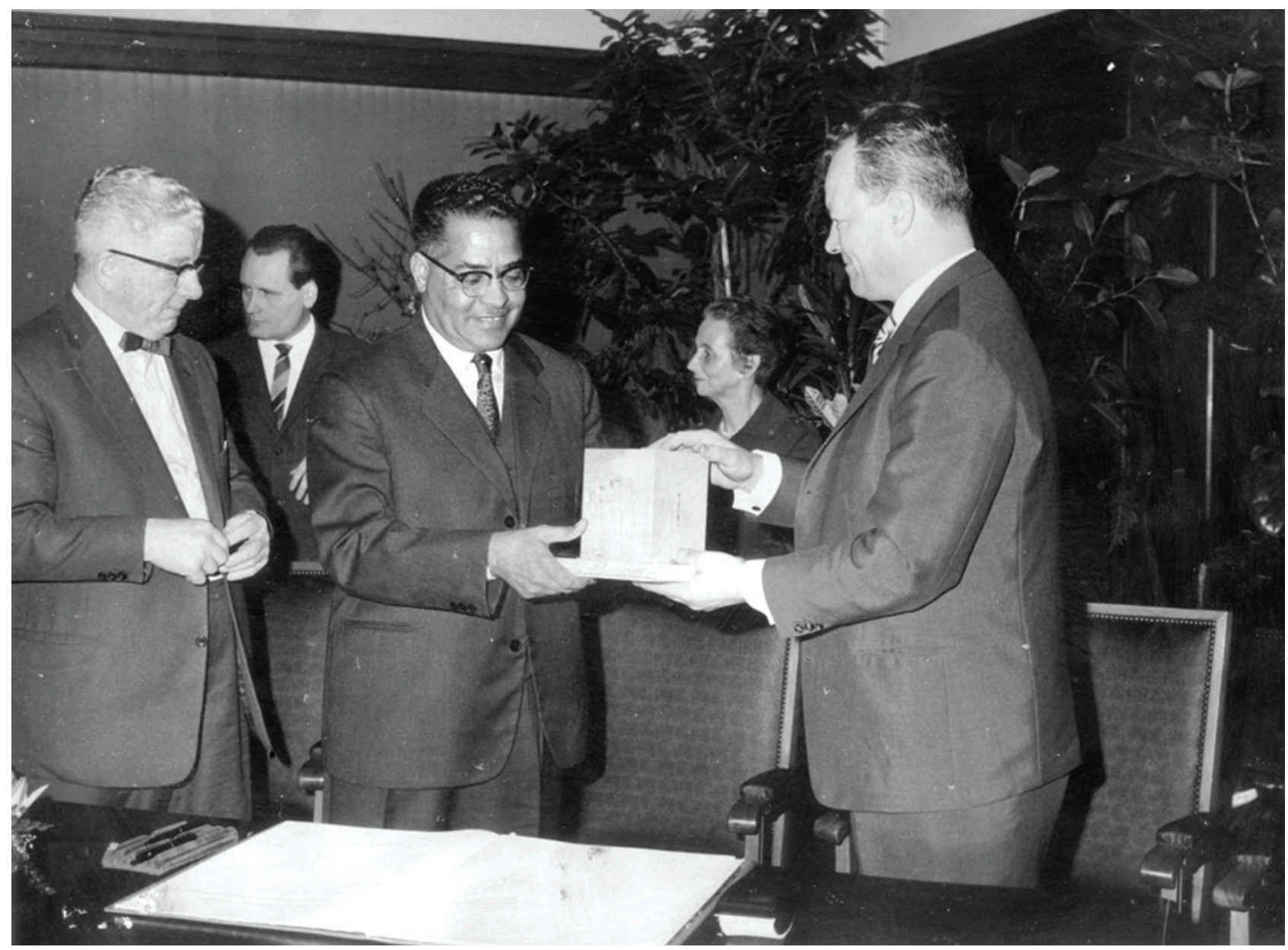

Figure 4 - As Mayor of Omdurman City, Professor Mansour Ali Haseeb (middle) was invited to visit Berlin in 1963 by Willy Brandt (right), Mayor of West Berlin (1957 - 1966) who later became Chancellor of the Federal Republic of Germany (1969 to 1974) and was awarded the Nobel Peace Prize in 1971. 


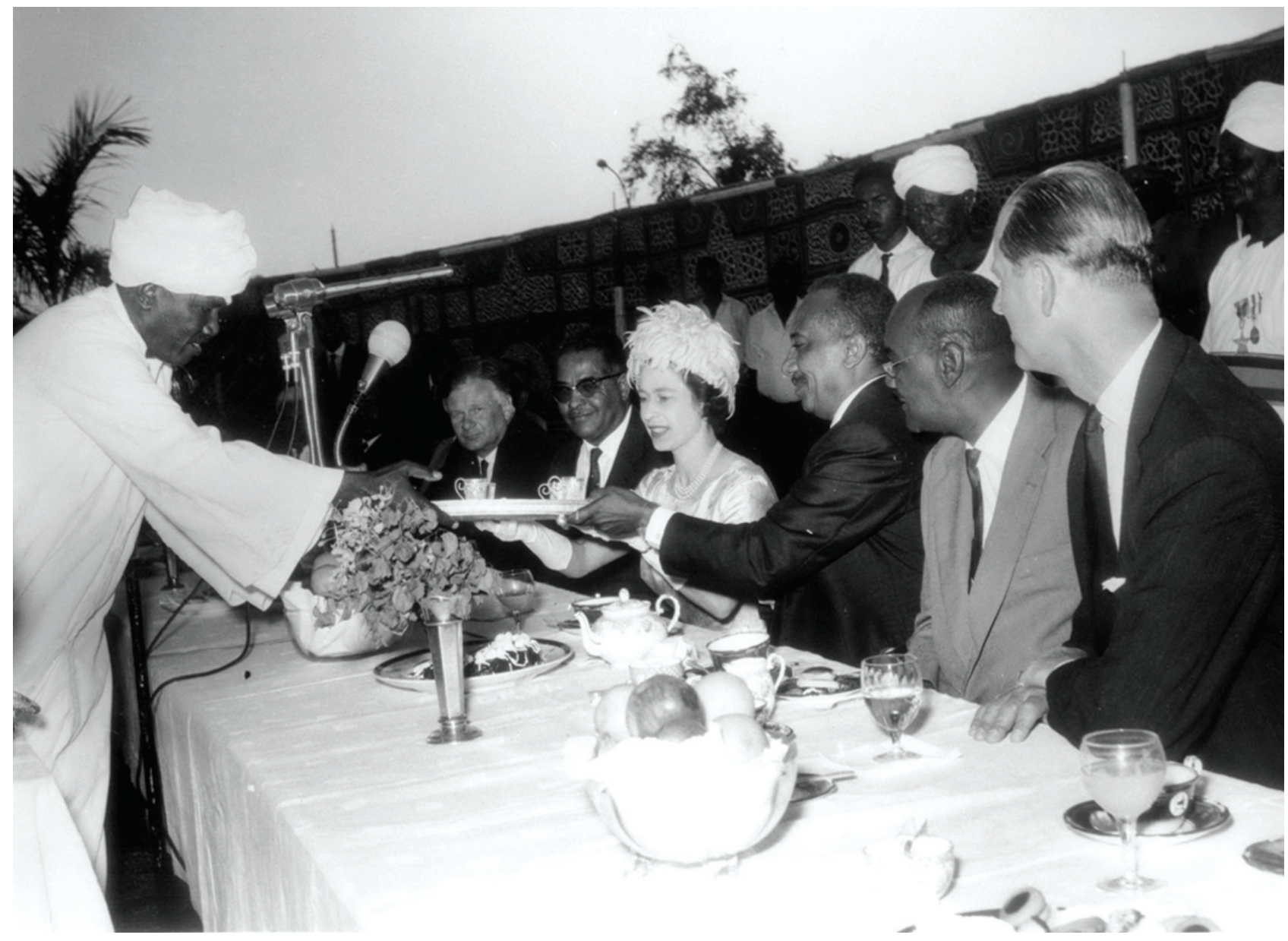

Figure 5 - City of Omdurman welcoming Queen Elizabeth II during her visit to Sudan in February 1965. From right: Prince Philip Duke of Edinburgh and Dr Tigani El Mahi, President of the Supreme Council of State (second from right). Professor Mansour Ali Haseeb (Mayor of Omdurman City) is sitting to the right of the Queen.

\section{Last achievements}

In 1970 a National Council for Research (NCR) was established in Sudan by a Presidential Decree. In 1973 the constitution of the NCR was amended and it consisted of four sub-councils. Professor Haseeb was appointed Chairman of one of these: The Sudan Medical Research Council.

The climax of Professor Haseebs' research is a joint work which constituted one of the first two randomized controlled trials which showed that polysaccharide serogroup A vaccine prevented serogroup A meningococcal meningitis [23]. The trial involved 21,640 individuals the majority of whom were children of both sexes. The study was supported by the Ministry of Health and Social Welfare, Sudan; the National Council for Research, Sudan; the University of Khartoum, Sudan; and the US Naval Medical Research Unit No. 3 (NAMRU-3), Cairo, Egypt. It was sponsored and assisted by the WHO Eastern Mediterranean Regional Office, Alexandria, Egypt, and published in 1973 after Professor Haseeb has passed away.

The effective implementation of the vaccine, in an anticipaction of an epidemic, was later found to 
abort it [24]. This mass vaccination was used later in Sudan, and the Author had the chance to be involved in it. A large epidemic of group A sulphonamideresistant MC disease swept Sudan in 1988 during an ongoing Sudanese/Swedish prospective study on childhood meningitis [25]. Between February and August 1988, 10 000 cases were recorded in Greater Khartoum of whom $50 \%$ were children $(<15$ years old) $[26,27]$. During the period March to July 1988, a mass immunization campaign, using bivalent $\mathrm{A} / \mathrm{C}$ polysaccharide vaccine, was launched and a total of $2,400,000$ individuals were vaccinated [27].

1n an international recognition of his outstanding services to medical education and research, Professor Haseeb was awarded Dr A.T. Shousha Prize and Medal in 1973 (Figures 6 and 7). The Prize, which is presented at a special ceremony during a session of the WHO Regional Committee for the Eastern Mediterranean, is awarded to those who have made the most significant contribution to improving health in the Eastern Mediterranean, the geographical area in which Dr A.T. Shousha served the Organization as WHO Regional Director [28]. Shortly thereafter, Professor Haseeb passed away on Saturday $29^{\text {th }}$ September 1973. His sudden death was a great shock to the medical profession in Sudan and beyond.

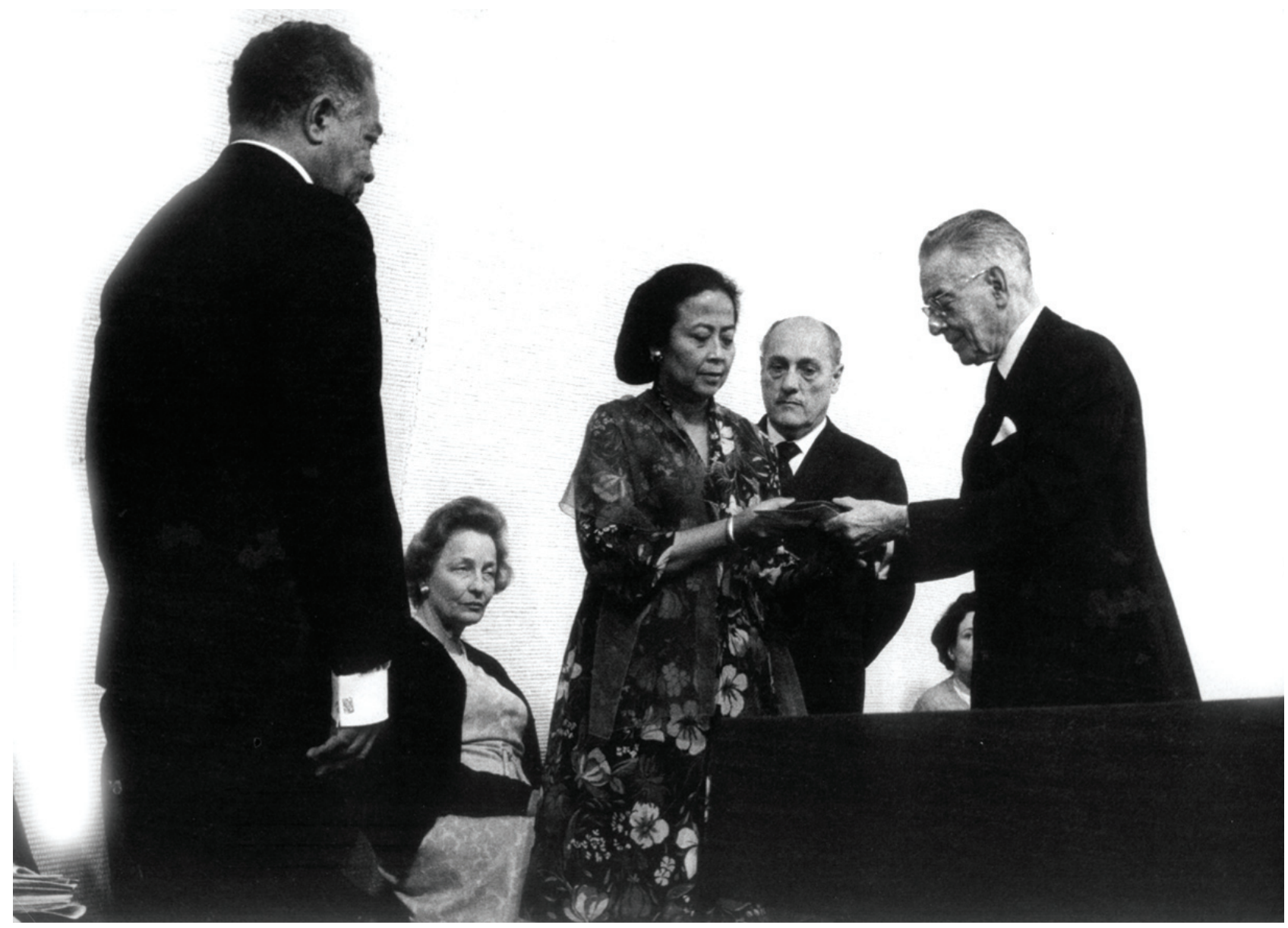

Figure 6 - Professor Mansour Ali Haseeb (left) receiving Dr A.T. Shousha Prize and Medal in 1973, awarded by the WHO to those who have made the most significant contribution to improving health in the Eastern Mediterranean Region. 


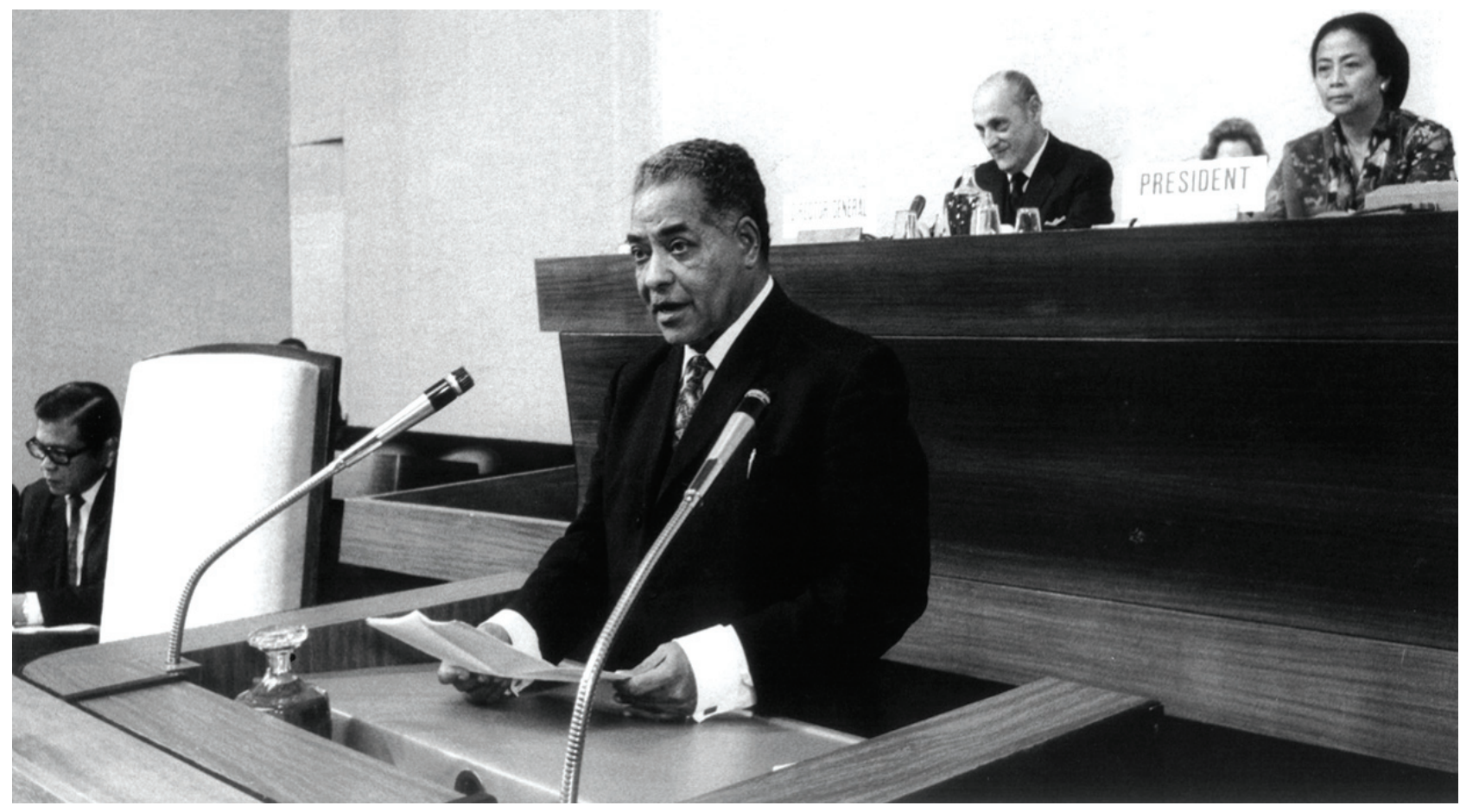

Figure 7 - Professr Mansour Ali Haseeb addressing the special WHO ceremony when receiving Dr Shousha Prize and Medal in 1973.

\section{ACKNOWLEDGEMENT}

The author would like to sincerely thank Dr Hatim Mansour Ali Haseeb for all the information and photos which laid the foundation for this article. Thanks are also due to Prof Abdel-Galil M. Abdel-Gader, College of Medicine and Adil Magzoub Ali Haseeb, PhD, Department of Physics and Astronomy, College of Science, King Saud University, Riyadh, Saudi Arabia for the help and support they gracefully offered.

\section{REFERENCES}

1. Haseeb M A. A Monograph on Biomedical Research in the Sudan. Khartoum: Khartoum University Press, 1973.

2. Keirans J E. Harry Hoogstraal (1917-1986). J Med Entomol 1986; 23: 342-3.

3. Curriculum Vitae of Professor E. N. Dafaalla. Avaialable at : https://www.facebook.com/media/set/?set=a.38700256 4714519.92203.353021158112660\&type=3\#!/photo.php?fbid=392276424187133\&set=a.387002564714519.92203 $.353021158112660 \&$ type $=3 \&$ theater. Accessed September 20, 2013.

4. Dafaalla E N, MA. Studies on Agglutination of Red Cells by Clostridia. I. Cl. Septique. Br J Exp Pathol. 1951; 32(6): $510-515$.

5. Omer EE, Habiballa N, Dafaalla EA. Evaluation of the standard agglutination test in the diagnosis of human brucellosis in the Sudan. J Trop Med Hyg. 1978; 81(10):190 - 194.

6. Berber, Sudan. Available at: http://en.wikipedia.org/wiki/Berber,_Sudan. Accessed September 20, 2013.

7. Baashari MO. Pioneers of Sudanese Thought (in Arabic). The House of Thought, Khartoum 1981: 389 - 392. 
8. Qasim AA. Sudanese Encyclopedia of Tribes and Genealogies (Volume 2). Maktabat Afiruqraf (Afro-Graph), Khartoum 1996: 624.

9. Lobban RA, Kramer RS, Fluehr-Lobban c, eds. Historical Dictionary of the Sudan (African Historical Dictionaries). Lanham and London: Scarecrow Press, 2002:181 - 182.

10. Haseeb MA. Tearing of the Medulla Oblongata due to a Jerk.1940. Brit Med J 1940; 1: 891. Available at: http:// europepmc.org/articles/PMC2177563/pdf/brmedj041470015-.pdf. Accessed September 20, 2013.

11. Horgan ES, Haseeb MA. Cross immunity experiments in monkeys between variola, alastrim and vaccinia. J Hyg (Lond). 1939; 39: 615-637.

12. Horgan ES, Haseeb MA. Revaccination as a measure of immunity to smallpox. J Hyg (Lond) 1944; 43(5):337- 340.

13. Haseeb MA. Undulant fever in the Sudan. J Trop Med Hyg 1950; 53 (12):241 - 244.

14. Taylor RM, Haseeb MA, Work TH. A regional reconnaissance on yellow fever in the Sudan; with special reference to primate hosts. Bull WHO 1955;12:711 - 725.

15. Reconnaissance for Yellow Fever in the Nuba Mountains, Southern Sudan in 1954, 2006. Accessed November 20 , 2013 at: http://www.nlm.nih.gov/hmd/collections/films/medicalmoviesontheweb/yellowfeversudan.html.

16. Haseeb MA. Terramycin in the Treatment of Experimental Rabies in Mice. Nature 1952;170: 983.

17. Haseeb MA. Purification of vaccine lymph with phenol. Lancet 1951; 257 (6646):114.

18. Haseeb M A. “Nilodin” in Treating Schistosoma Haematobium. Br Med J 1952; 21: 1(4772): 1331-1332.

19. Haseeb M A. Observations on an outbreak of smallpox in Mesektab. Sudan Med J 1962; 1(3):143 - 145.

20. Haseeb M A. On the history of kala azar in the Sudan. Al hakeem 1959; 7:39.

21. Khalil S I. Medical services in Sudan: a historical perspective. Sudan Med J 2013; 49(1):5060-. Available at: http:// www.smj.eg.net/journals/pdf/261.pdf. Accessed September 28, 2013.

22. Beshir MO. Educational Development in the Sudan, 1898 to 1956. Oxford: Clarendon Press, 1969.

23. Erwa HH, Haseeb MA, Idris AA, Lapeyssonie L, Sanborn WR, Sippel JE. A serogroup A meningococcal vaccine. Studies in the Sudan to combat meningococcal meningitis caused by Neisseria meningitidis group A. Bull WHO 1973;49:301-305.

24. Hu Z, Rou YL, Chen C, Chen RS, Wu QK, Zhang VY, et al. An epidemiological and serological study on duration of protection after meningococcal group A polysaccharide (APS) vaccination. In: Poolman JT, Zanen HC, Meyer TF, Heckels JE, Makela PH, Smith H, Beuvery CE (eds). Gonococci and Meningococci. London: Kluwer Academic Publishers, 1988: 199207-.

25. Salih MAM, Ahmed HS, Osman KA, Kamil I, Palmgren H, Hofvander Y, Olcen P. Clinical features and complications of epidemic group A meningococcal disease in Sudanese children. Ann Trop Paediatr 1990; 10:231 - 238.

26. Karrar ZA, Bashaar S, Salih MAM. Mortality among children with meningococcal disease: An analysis of deaths during the 1988 epidemic. Sudan Med J 1990; 28: 14-. Available at: https://www.researchgate.net/ publication/236897162_MORTALITY_AMONG_CHILDREN_WITH_MENINGOCOCCAL_DISEASE_AN_ ANALYSIS_OF_DEATHS_DURING_THE_1988_EPIDEMIC?ev=prf_pub. Accessed September 26, 2013.

27. Salih MAM. Childhood acute bacterial meningitis in the Sudan: An epidemiological, clinical and laboratory study. Scand J Infect Dis 1990; Supplement 66:1 - 103.

28. World Health Organization. Dr A.T. Shousha Foundation Prize and Fellowship. Available at: http://www.who.int/ governance/awards/shousha/en/. Accessed September 20, 2013. 